\title{
Knowledge selection in initial teacher education programmes and its implications for curricular coherence
}

\section{Lee Rusznyak}

\begin{abstract}
There are a multitude of concepts and techniques that could be important for teachers to learn during their initial teacher education (ITE), but indiscriminately including all of them would result in an overcrowded and fragmented curriculum. Given the limited time for ITE, rational knowledge selection choices must be made if coherent programmes are to be offered to prospective teachers. This paper explores the approaches taken to addressing the critical challenges facing education in South Africa and the principles from knowledge selection that arise from these approaches. Different conceptions about how best to address these challenges offer directed priorities to guide knowledge selection decisions for ITE curricula. Examples of knowledge selection principles that variously promote conceptual or contextual coherence are presented and analysed, and tradeoffs associated with each one are considered. Although some recontextualising principles are mutually incompatiable, others have the potential to coexist. In a four-year qualification, where sequencing choices can be made, there exists the possibility of introducing different principles at different times without unduly compromising internal coherence. A challenge for those who design ITE curricula is to design conceptually coherent and/or contextually responsive curricula fully aware of the affordances and limitations offered by different recontextualising principles.
\end{abstract}

\section{Introduction}

There are a myriad of views about what should be prioritised in initial teacher education (ITE) curricula. The knowledge selection for compulsory courses is especially contentious because it is deemed to represent what a university regards as the core knowledge that is essential for all prospective teachers, irrespective of their subject and/or phase specialisations. It might be tempting to give student teachers fleeting exposure to a multitude of theories, tips, techniques, concepts, skills and practices that may be regarded as important for all teachers to learn. However, this approach would result in overcrowded and fragmented, incoherent curricula, which would do little to support the developing practices of teachers. When student teachers do not understand the 
overarching framework/s that informs the internal logic of their ITE curriculum, they find it difficult to make sense of the relation between the different courses they do (Hoban, 2005). It is the task of curriculum designers to devise a coherent structure that enables teacher educators to select knowledge from the disciplinary field in which it is created, or from the field of practice, and then recontextualise it into a form that can be acquired by prospective teachers during their ITE programme (Bernstein, 2000).

Curricular coherence can be enhanced by the intentional use of recontextualising principles that guide decisions about "what [knowledge] gets selected, how it is sequenced, paced and evaluated" (Shay, 2013, p.4). ITE programme and course designers have the responsibility to "be aware of such [knowledge selection and sequencing] choices and should account for those that they do make" (Winch, 2014, p.59). Recontextualising principles provide the basis on which some concepts are brought to the fore as explicit objects of study, while other concepts are included but backgrounded, and inevitably, some learning is left for on-the-job acquisition. In addition, recontextualising principles provide the basis on which the internal logic, and relative strengths, weakness and gaps in an ITE curriculum can be identified, and comparisons over curricula can be made. While other recent papers on teacher knowledge in South African ITE programmes (e.g. Bertram and Christiansen, 2012; Reeves and Robinson, 2014) explore how different approaches to ITE are based upon different assumed relationships between theoretical knowledge and practice, this paper explores how choices of recontextualising principles brings particular kinds of teacher knowledges to the fore in parts of formal university-based coursework. The main claim of this paper is that recontextualising principles enhance the internal coherence of ITE programmes, and offer a gainful approach to addressing the challenges experienced in the South African education system. However, because they bring particular kinds of teacher knowledge to the forefront of teacher development, other kinds of teacher knowledge are inevitably backgrounded. The potential trade-offs associated with each recontextualising principle need to be better understood for the sector to make deliberate and informed choices when selecting knowledge for ITE currcula. 


\section{Initial teacher education in South Africa:} a brief overview

The nature of ITE curricula offered to prospective teachers is increasingly under the scrutiny, both in terms of analysing the role that inadequate teacher training played in contributing to the current crisis of education in South Africa, and the provision of quality ITE programmes as a potential means to addressing that same crisis (Osman, 2010; Reeves and Robinson, 2014; Taylor, Van der Berg and Mabogoane, 2013). The recently revised policy governing the provision of teacher education, the Minimum Requirements for Teacher Education Qualifications (henceforth, MRTEQ) identifies several "critical challenges" facing education in South Africa: the "poor content and conceptual knowledge found amongst teachers, as well as the legacies of apartheid" (Department of Higher Education and Training [DHET]), 2015, p.11). ${ }^{1}$ This is not surprising given that during apartheid, in the worst cases, some teacher training colleges offered prospective teachers a rudimentary level of content knowledge, a collection of classroom survival tips and very little conceptual understanding of education, schooling, teaching and learning (Welch, 2002). Since 2002, when the provision of teacher education was moved into the higher education sector, qualifying teachers are required to hold a bachelors degree and/or a professional qualification. This may comprise either a 3-year academic degree with a one year post-graduate professional qualification, or a four-year professional Bachelor of Education (BEd) degree.

To emphasise the importance of producing knowledgeable and responsive teachers for the South African context, MRTEQ explicitly rejects the technicist approach that characterised much of the teacher training offered during apartheid. MRTEQ adopts a knowledge-based approach and requires that all ITE curricula should include specified proportions of disciplinary learning (which includes educational theoretical knowledge, as well as subject content knowledge and its associated skills), pedagogical learning (including general pedagogical knowledge and pedagogical content knowledge), practical learning (knowledge acquired from observing, analysing and reflecting on one's own teaching and the teaching of others),

1 This differs from other studies that identify the challenge as being teachers' weak content and pedagogic knowledge (e.g. NEEDU study). 
situational learning (learning about the diverse contexts in which education exists) and foundational learning (the generic knowledge and competences that are not teacher-specific, but might be useful in the day-to-day work that teachers do). ${ }^{2}$ Despite its assertion that MRTEQ "brings the importance of interconnectedness between different types of knowledge and practices into the foreground" (p.10), the five types of teacher learning are listed by the policy as distinct and separate entities. ITE curricula could very well be policy-compliant but still offer unnecessarily fragmented and incoherent learning programmes to prospective teachers if each type of knowledge is developed within stand-alone modules without an overall organising framework.

\section{The nature of theoretical and practical knowledge for education}

The relationships between these different types of knowledge listed by MRTEQ cannot be derived from policy, nor are they self-evident. I now draw on the semantic dimension of Maton's (2007) Legitimation Code Theory to analyse how types of teacher learning as required by MRTEQ (DHET, 2015) differ in the respective strengths of their semantic densities and semantic gravities. Semantic density is the extent to which meaning is conveyed through abstracted concepts emerging from outside the field of practice, and expressed in a specialist, symbolic language. Semantic gravity, by contrast, is the extent to which meaning is fundamentally linked to the context in which the knowledge was created. The discussion that follows is summarised in Table 1 below:

The first four of these categories constitute a specialist knowledge base for prospective teachers, and are thus of relevance in this paper. Generic (Foundational) knowledge has a weak semantic gravity (SG-) and a weak semantic density (SD-), and corresponds to what MRTEQ (2011) refers to as foundational learning. 
Table 1: Table showing the types of teacher learning required of MRTEQ (2015), the associated knowledges and the semantic densities and gravities associated with each one

\begin{tabular}{|c|c|c|}
\hline $\begin{array}{l}\text { Types of teacher } \\
\text { learning } \\
\text { MRTEQ (2015) }\end{array}$ & Knowledge to be included in ITE curricula & $\begin{array}{l}\text { Semantic } \\
\text { density and } \\
\text { Semantic } \\
\text { gravity }\end{array}$ \\
\hline \multirow[t]{2}{*}{$\begin{array}{l}\text { Disciplinary } \\
\text { learning }\end{array}$} & 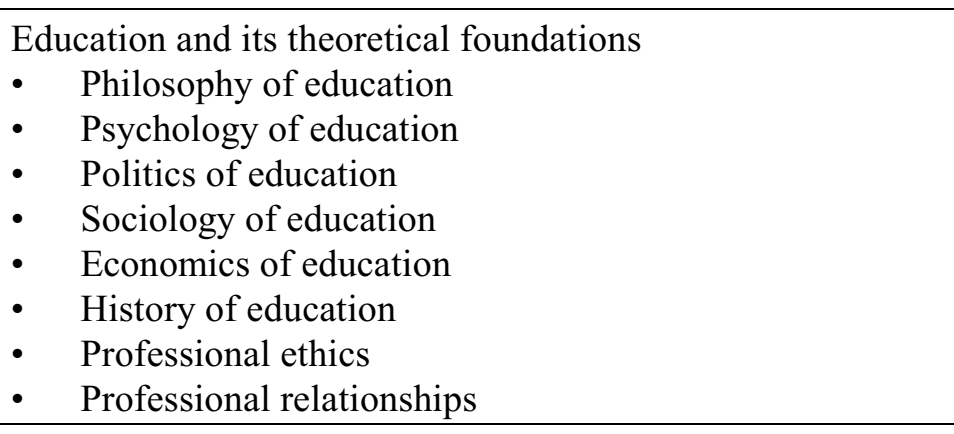 & \multirow[t]{2}{*}{$\mathrm{SD}+\mathrm{SG}-$} \\
\hline & Subject matter knowledge & \\
\hline \multirow[b]{2}{*}{$\begin{array}{l}\text { Pedagogical } \\
\text { learning }\end{array}$} & $\begin{array}{l}\text { Pedagogical content knowledge } \\
\text { Inclusive education }\end{array}$ & $\mathrm{SD}+\mathrm{SG}+$ \\
\hline & $\begin{array}{ll}\text { General pedagogical knowledge: } \\
\text { - } & \text { Learners } \\
\text { - } & \text { Learning } \\
\text { - } & \text { Curriculum } \\
\text { - } & \text { General instructional strategies } \\
\text { - } & \text { Assessment strategies } \\
& \text { Inclusive education }\end{array}$ & SD- SG+ \\
\hline \multirow{2}{*}{ Practical learning } & $\begin{array}{l}\text { Learning from practice: } \\
\text { - Craft knowledge from observing, reflecting on lessons } \\
\text { of others }\end{array}$ & $\mathrm{SD}-\mathrm{SG}+$ \\
\hline & $\begin{array}{l}\text { Learning in practice: } \\
\text { - Tacit knowledge from preparing, teaching, reflecting on } \\
\text { lessons }\end{array}$ & SD- SG+ \\
\hline $\begin{array}{l}\text { Situational } \\
\text { learning }\end{array}$ & $\begin{array}{l}\text { - Learning situations, contexts, environments } \\
\text { - Prevailing policy, political, organisational contexts }\end{array}$ & $\mathrm{SG}^{+}$ \\
\hline $\begin{array}{l}\text { Foundational } \\
\text { learning }\end{array}$ & $\begin{array}{l}\text { - Communicative competence in additional language/s } \\
\text { - Information Computer Technologies } \\
\text { - Academic literacy }\end{array}$ & SD- SG- \\
\hline
\end{tabular}


The nature of disciplinary knowledge

The MRTEQ category of disciplinary learning encompasses theoretical knowledge that has a very strong semantic density $(\mathrm{SD}+)$ because of its reliance on conceptual and symbolic ideas. It has a weak semantic gravity (SG-) because it provides generalisable principles that transcend contextual specificities. MRTEQ specifies two forms of theoretical knowledge that can underpin rational judgement in practice (Shalem, 2014): disciplinary knowledge associated with the study of education, and the subject knowledge that gives rise to school subjects. Acquisition of theoretical knowledge requires an understanding of the boundaries and structure of the discipline in which it is produced, the ability to locate concepts in their sub-field within the discipline, and the ability to infer relationships between concepts within that discipline (Guile, 2014). Theoretical ideas about education cannot be accessed through the personal experiences of student teachers, and are recontextualised into ITE curricula from disciplines including psychology, sociology and philosophy. Theoretical knowledge is crucial if prospective teachers are to develop systematic, analytical and powerful ways of thinking about schooling, education, teaching and learning (Slonimsky and Shalem, 2006). Although the insights offered cannot be directly applied in practice, they do provide the conceptual tools to think of possibilities beyond the present contextual structures.

In order for teachers to introduce learners to the knowledge practices of the subjects they teach, they need to understand the big ideas that provide organising insights (Wiggins and McTighe, 2005), they need to be able to locate concepts within the knowledge structures of the subject, see relations between concepts, and understand the methods of inquiry through which that knowledge is created and validated (Winch, 2014). Shalem (2014) insists that subject knowledge, like education theory, provides a legitimate epistemic basis for the professional acumen of teachers. Subject knowledge dictates the most conceptually appropriate pedagogic choices (Ball, Thames and Phelps, 2008; Morrow, 2007). Teachers of mathematics, teachers of early literacy, teachers of history or of science draw on different reservoirs of pedagogical knowledge that is specific to their discipline, and to the needs of learners in the contexts in which they teach. The application of pedagogy in practice is therefore logically dependent on content knowledge, and cannot be derived from general principles about teaching. Pedagogical content knowledge 
(PCK) is therefore regarded as a specialist professional knowledge (Shulman, 1987), with a strong semantic density and a strong semantic gravity (SD+ $\left.\mathrm{SG}^{+}\right)$.

The nature of practical and pedagogical knowledge

Practical knowledge is derived from the cumulative experience of 'what works' by those who participate in the practice. Practical knowledge is therefore produced by teachers (and other practitioners) working within classroom environments (not outside of it, like theoretical knowledge). It is characterised by a strong semantic gravity $\left(\mathrm{SG}^{+}\right)$because it finds meaning in the contexts of practice. It has a much weaker semantic density (SD-) than theoretical knowledge as it relies less on symbolic language and concepts (Maton, 2007; Shay, 2013). While formalised practical knowledge (what MRTEQ calls General pedagogical knowledge) may possibly be acquired by student teachers through reflections on their classroom experiences, the ad hoc nature of learning in practice means that this is an unreliable way of ensuring intended learning (Gamble, 2006). Principles governing practice that have been codified and shared between practitioners can more efficiently and systematically be learnt in formal university-based coursework, in what MRTEQ refers to as Pedagogical learning, and through carefully constructed opportunities to learn from the analysis of exemplary practice. Practical learning can thus be acquired formally as General pedagogical knowledge through university-based coursework, or acquired more tacitly from personal experience and the craft knowledge that is transmitted between teachers in situ. The potential for the systematisation of practical knowledge is greatest when acquisition is formalised into university-based coursework, and most contingent when acquired in situ as and when the need arises.

The nature of situational knowledge

Situational knowledge, by its nature, has a strong semantic gravity $\left(\mathrm{SG}^{+}\right)$, but unlike practical knowledge, it is neither decontextualised theoretical knowledge nor does it arise out of the practices of teachers in the field. It is largely descriptive in nature, although aspects of it may be disciplinary, if a historical framework is used to analyse the way in which the present context came to be. In the context of South Africa, situational knowledge is 
considered important partly because the legacy of apartheid has left education in marginalised communities in a state of extreme crisis (Gardiner, 2008), and partly because of the considerable diversity of schooling that characterises the South African education system (Fleisch, 2007).

\section{Enhancing curriculum coherence in ITE}

Coherent ITE curricula are difficult to design because potentially relevant and legitimate knowledge can be selected from vastly different knowledge sources. For example, knowledge can variously be drawn from theoretical disciplines that offer educationally relevant insights; the innovative and shared practices of expert teachers; the perceived needs of teachers in a range of contexts; and the personal classroom experiences of those who teach the teachers (Guile, 2014). While theoretical and practical knowledge can both be related through professional practices, they have distinct epistemic roots, and neither one can be derived from the other (Muller, 2009; Shay, 2013).

Although MRTEQ expects that the different kinds of knowledge should come together in an integrated way in the moment of practice, the teacher education literature suggests that that integration of knowledge bases in practice is something that occurs neither easily nor automatically (Bertram and Christiansen, 2012; Hammerness, Darling-Hammond, Bransford, Berliner, Cochran-Smith, McDonald and Zeichner, 2005; Hoban, 2005).

Muller (2009) offers two main routes of promoting coherence in curricula designed to support professional practices: through contextually-driven coherence and through conceptually-driven coherence. Contextually-driven ITE curricula provide prospective teachers with a set of contingent skills and knowledges directly relevant to meeting the demands of classroom life and the realities of the contexts in which they will practice. Conceptually-driven coherence in ITE curricula enables prospective teachers to acquire a systemitised body of theoretical knowledge which they can draw principles from for informing rational judgement in their practice. While some recontextualising principles for coherent ITE curriculum design will enhance the contextual coherence of the programme, others will lead to a stronger degree of conceptual coherence. In both cases, they provide ways of connecting different courses within an ITE programme into a relational 'whole'. However, because recontextualising principles bring to the fore certain kinds of teacher knowledge, the conceptualisation of coursework 
follows the logic of that knowledge. Other kinds of knowledge may be selected for learning in support of that recontextualising principle, but may not necessarily be presented as coherent bodies of knowledge in their own right.

The disciplines that inform education theory, according to Bernstein (2000), have horizontal knowledge structures: knowledge of educational theory grows by understanding the insights offered by different theoretical frameworks rather than seeking increasing levels of abstraction. The fact that concepts arising from education theory have a strong semantic density but a weak semantic gravity make it possible to attain some degree of conceptual coherence in ITE curriculum design, despite its predominantly horizontal knowledge structure. Recontextualising principles suggest different approaches to addressing the challenges in the South African education system which essentially demands a consideration of responsiveness to contextual factors. Some approaches are led by knowledge that has strong semantic density and others by knowledge that has strong semantic gravity. In reality, it is not always possible neatly to align different programmes (or the courses within them) with contextual or conceptual coherence, because as Shay (2013) points out, curricula that support professional practices need to equip prospective teachers with knowledge that has a strong semantic density and a strong semantic gravity. Both are needed for the development of conceptually informed practice. However, the distinction that Muller (2009) makes serves as a useful heuristic device that enables an analysis of how particular principles guide knowledge selection and sequencing to support the overall intention of an ITE programme.

\section{Principles for coherent knowledge selection}

In this section, I draw on some of the literature about teacher education in South Africa to extract examples of recontextualising principles that could potentially inform the design of coherent ITE curricula. Each principle suggests a different approach to addressing some of the 'critical challenges' facing education in South Africa, and would bring particular kinds of teacher knowledge to the fore in an ITE curriculum. While by no means exhaustive, the potential gains and drawbacks of five examples of recontextualising principles will be considered in this section. 
Table 2: Summary showing examples of recontextualising principles and their implications for curricular coherence and teacher knowledge

\begin{tabular}{|l|l|l|l|}
\hline \multicolumn{1}{|c|}{$\begin{array}{l}\text { Teacher knowledge } \\
\text { that would be } \\
\text { foregrounded }\end{array}$} & $\begin{array}{l}\text { Teacher } \\
\text { knowledge that is } \\
\text { present but would } \\
\text { be backgrounded }\end{array}$ & $\begin{array}{l}\text { 年asis for } \\
\text { curricular } \\
\text { coherence }\end{array}$ \\
\hline $\begin{array}{l}\text { Teachers develop relevant } \\
\text { teaching practices when they } \\
\text { are prepared for particular } \\
\text { kinds of South African } \\
\text { schools. }\end{array}$ & Situational knowledge & $\begin{array}{l}\text { Theoretical } \\
\text { knowledge, subject } \\
\text { matter knowledge }\end{array}$ & $\begin{array}{l}\text { Tends towards } \\
\text { contextual } \\
\text { coherence }\end{array}$ \\
\hline $\begin{array}{l}\text { Teachers develop meaningful } \\
\text { teaching practices through a } \\
\text { personalised process of self- } \\
\text { discovery and reflective } \\
\text { practice. }\end{array}$ & $\begin{array}{l}\text { Personal practical } \\
\text { knowledge }\end{array}$ & $\begin{array}{l}\text { Theoretical } \\
\text { knowledge, subject } \\
\text { matter knowledge }\end{array}$ & $\begin{array}{l}\text { Tends towards } \\
\text { contextual } \\
\text { coherence }\end{array}$ \\
\hline $\begin{array}{l}\text { Teachers develop realistic } \\
\text { teaching practices when they } \\
\text { are well prepared for the } \\
\text { demands of classroom life. }\end{array}$ & $\begin{array}{l}\text { General pedagogical } \\
\text { knowledge, situational } \\
\text { knowledge }\end{array}$ & $\begin{array}{l}\text { Theoretical } \\
\text { knowledge, subject } \\
\text { matter knowledge }\end{array}$ & $\begin{array}{l}\text { Tends towards } \\
\text { contextual } \\
\text { coherence }\end{array}$ \\
\hline $\begin{array}{l}\text { Teachers develop more } \\
\text { socially just teaching } \\
\text { practices when they can resist } \\
\text { the constraints of present } \\
\text { practices that compromise } \\
\text { teaching and learning } \\
\text { imperatives. }\end{array}$ & $\begin{array}{l}\text { Theoretical knowledge; } \\
\text { Pedagogical knowledge }\end{array}$ & $\begin{array}{l}\text { Personal practical } \\
\text { knowledge }\end{array}$ & $\begin{array}{l}\text { Tends towards } \\
\text { conceptual } \\
\text { coherence }\end{array}$ \\
\hline $\begin{array}{l}\text { Teachers develop effective } \\
\text { teaching practices when they } \\
\text { are able to provide all } \\
\text { learners access to powerful } \\
\text { knowledge across diverse } \\
\text { contexts. }\end{array}$ & $\begin{array}{l}\text { Theoretical knowledge, } \\
\text { pedagogical knowledge }\end{array}$ & $\begin{array}{l}\text { Personal practical } \\
\text { knowledge }\end{array}$ & $\begin{array}{l}\text { Tends towards } \\
\text { conceptual } \\
\text { coherence }\end{array}$ \\
\hline
\end{tabular}

1. Teachers develop relevant teaching practices when they are prepared for particular kinds of South African schools.

This recontextualising principle is located in a wider philosophical position that insists that teaching is so contextually embedded that it cannot be studied and developed outside of the context in which it happens (Carr, 2006). It suggests that ITE programmes should be contextually specific. An ITE curriculum that prepares teachers for rural schools is assumed to need substantially different set of knowledge and skills to that which prepares teachers to teach in urban schools, for example. Advocates of this position argue that there are strong urban biases in many ITE curricula, and these 
compromise teachers' ability to be relevant within non-urban school contexts. In response to the critical challenges in South African education, this recontextualising principle would seek to prepare prospective teachers with particular local knowledge and the specific set of skills they need for teaching learners, within particular contexts (e.g. Balfour, Mitchell and Moletsane, 2008; Gardiner, 2008; Mukeredzi and Mandrona, 2013). A programme that seeks to address the critical challenges using this knowledge selection principle would seek strong contextual coherence, and would foreground the importance of situational knowledge, which would in turn stress the importance of identifying the local knowledge and skills that would enable prospective teachers to teach in ways relevant to local contexts. What constitutes an appropriate pedagogic choice would have more to do with the contextual possibilities than what is best served by the subject matter to be learnt.

Critics of contextually-specific approaches to the design of ITE curricula argue that the particularities of local contextual knowledge can be acquired relatively quickly in situ, but the non-intuitive insights that decontextualised education theory provides cannot easily be acquired outside formal mediation. Curricula designed around this recontextualising principle are likely to underestimate the power that abstracted theoretical knowledge has in providing insights over diverse contexts (Morrow, 2007). Good teaching, it is argued, by its very nature, is responsive to learner and contextual diversity. According to this view, attempts to prepare teachers for specific contexts are more likely to entrench rather than alleviate inequalities, as the emphasis is on contextual relevance and not the powerful knowledge that enables teachers (and their learners) to participate in nationally important conversations that transcend local contexts (Wheelahan, 2010; Young, 2008).

\section{Teachers develop meaningful teaching practices through a personalised process of self-discovery and reflective practice.}

This approach to addressing the critical challenges in education seeks to bridge a disconnect between the students' personal identity and cultural context, and the decontextualised ideals of schooling. This recontextualising principle privileges the personal development of teachers, and considers their identity, beliefs and motivation to be fundamental parts of their learning to teach (Korthagen, 2004; Samuel, 2002, 2008). A curriculum designed around this recontextualising principle seeks to enable student teachers to articulate their personal mission and philosophies of teaching, as well as develop their 
professional identities and their teaching competences, so they can make sense of their behaviours in classroom environments. This approach has its roots within a constructivist view of teaching and learning. Learning to teach is thus conceptualised as a process of self-discovery that consolidates and builds on students' personal knowledge and previous educational experiences. It happens to a large extent through guided introspection, accumulated experience and reflection. It seeks to produce teachers who are 'reflective practitioners', who learn through trial-and-error, and who depend on their personal practical knowledge to learn to make wise judgements in practice (Schön, 1987). The ability to teach is thus primarily legitimised by who teachers are, rather than what they know and can do with that knowledge independent of their personalities and their personally constructed mission for teaching (Maton, 2007).

This recontextualising principle foregrounds the construction of personalised practical knowledge that can be acquired through personal experiences (of observing, analysing the teaching of others, or through planning, teaching and reflecting on lessons). Personalised practical knowledge is by its nature contingent (and therefore not systematic), and contextually bound (and therefore not generally transferable). Samuel (2009) argues that ITE curricula that do not consider the influence of cultural, racial and gender identities and lived experiences of prospective teachers offer inappropriate models of teaching that do not hold traction when the students return to their communities. Education theory is thus not offered as a means to develop a systemitised understanding of the field, but as a means of enabling students to undertake processes of guided introspection and formulate their own philosophies of teaching.

While some (e.g. Samuel, 2008) advocate the ability of conscious reflection on teaching experience to develop teachers' practice, this approach is criticised on the grounds that it does little to offer prospective teachers the conceptual tools to take them beyond a common-sense approach to their teaching (Shalem, 2014; Shalem and Slonimsky, 2013) The relativist underpinnings provide a weak epistemological basis for teachers to make rational professional judgements in practice. 


\section{Teachers develop realistic teaching practices when they are well prepared for the demands of classroom life.}

This principle seeks to address a concern that many newly qualified teachers seem to leave teaching within a few years of graduating. In this view, a major reason for the attrition of newly qualified teachers is the disconnect between their expectations of teaching and the realties of classroom life. This recontextualising principle demands a highly relevant ITE curriculum where the anecdotal experiences of practitioners and their everyday experiences of classroom life provide the grounds for the selection of knowledge. Typically, a range of issues, dilemmas and concerns that arise from students' experience in practice, or from critical incidents from practicing teachers, form a point of departure (e.g. Gravett, Merseth and De Beer, 2013; Petersen and Henning, 2010). Early exposure to settings of practice is necessary and a thematic approach is used to explore theoretical implications and/or practical solutions to these issues, critical incidents or problems. Prospective teachers therefore become equipped with a set of contingent concepts and strategies that together could enable them to be adaptive to the possibilities, limitations and challenges of the context/s in which they will teach. This recontextualising principle foregrounds general pedagogical knowledge and personallyacquired practical knowledge and tends towards contextual coherence.

While ITE curricula may be directly relevant to classroom life, this approach is criticised on the basis of its anti-intellectualism because it comprises student teachers' acquisition of a systematic and coherent body of educational knowledge (Shalem and Slonimsky, 2013; Young and Muller, 2014). Education theory, while present, is drawn on in a contingent manner in service of concerns that arise in practice. This approach may provide immediate coping skills to newly-qualified teachers, but it is unlikely to provide them with the conceptual tools to respond in theoretically-informed ways to limitations and structural constraints associated with prevalent practices.

4. Teachers develop more socially just teaching practices when they can resist the constraints of present practices that compromise teaching and learning imperatives.

This recontextualising principle is based on the premise that many South African student teachers have come through (and upon qualification, return to) largely dysfunctional schooling systems, where pervasive practices that 
constrain teaching and learning have often become normalised (Fleisch, 2007; Taylor et al., 2013). Such practices include, for example, experiences related to learner exclusion and/or marginalisation, insufficient engagement with conceptual knowledge, limited opportunities for extended reading/writing classwork tasks, and the continuing use of corporal punishment. If newlyqualified teachers return to schools and continue these prevalent but counterproductive practices, they will merely perpetuate the challenges facing the South African education system. One task of ITE programmes is to distantiate prospective teachers from their experientially-acquired norms of teaching, to equip them with the conceptual tools to analyse (and where necessary, to revise and/or deepen) their assumptions about what constitutes effective teaching and learning. According to this view, ITE curricula should be structured around studies that provide prospective teachers with access to threshold concepts that open up "a new and previously inaccessible way of thinking about something" (Meyer and Land, 2003, p.1). They do not merely involve cognitive shifts, but a repositioning of the self in relation to the object of study and enable more sophisticated ways of thinking (Land, Cousin, Meyer, and Davies, 2005). Studies in education theory have the potential to provide access to such concepts, and therefore set potential conditions for student teachers to develop counter-intuitive insights in practice (Craib, 1992).

In taking a leading role in curricular coherence, a systematised body of education theory establishes conditions necessary for prospective teachers to draw on conceptually-informed insights when making professional decisions in practice. A theoretically-led approach to ITE curricula argues for less time spent building practical learning in classrooms. Learning in practice should wait until student teachers have sufficiently distantiated themselves from their assumptions about teaching and have developed a theoretical lens through which to understand the ways in which structural and classroom practices may constrain as well as enhance learning.

Such programnmes are routinely criticised on the basis that they are contextually remote and that they set up an unrealistic set of expectations and do not prepare newly-qualified teachers sufficiently for the realities of classroom life (Gravett, Henning, and Eiselen, 2011; Whitelaw, De Beer, and Henning, 2008). Their under preparedness leads to a 'shock' for newlyqualified teachers at the beginning of their careers, something that Gravett et al. (2011) suggest is a possible reason why numerous teachers leave teaching within five years of qualifying. Hoban (2005) contests this, arguing that 
newly-qualified teachers get overwhelmed when they don't have the conceptual tools to understand the complexity of their practice.

\section{Teachers develop effective teaching practices when they are able to provide all learners access to powerful knowledge across diverse contexts.}

The imperative to prepare teachers to work productively across diverse contexts provides the next recontextualisation principle. An abstracted concept of teaching which is contextually responsive but not contextually bound is used to consider the essential work that teachers do (Alexander, 2000; Morrow, 2007). The fundamental purpose of teaching is understood to be making epistemological access to powerful knowledge that resides within organised bodies of knowledge available to the learners in one's class (Wheelahan, 2010; Young, 2008). This imperative would not change across contexts, but the way in which teaching is operationalised varies from one context to another. Having a strong conception of teaching with a strong semantic density but a weak semantic gravity allows teachers to distinguish between the formal elements of teaching (which operate in all instances of teaching and are therefore context-independent), and the material elements which "are necessarily rooted in specific contexts" (Morrow, 2007, p.98). The key question for those learning to teach then becomes "How can I organise systematic learning in this context and [under] these [material] conditions?" (Morrow, 2007, p.105, italics my emphasis). Understanding the distinction between material and formal elements of teaching enables student teachers to analyse how structural factors may limit or enable the practice of teaching without trapping them into a notion that teaching can only take place under an ideal set of material conditions.

A common critique of teacher education programmes that have a strong theoretical orientation is that because teachers work under conditions of change, unpredictability and complexity, formalised educational theory is too removed from the contexts of practice to be helpful in guiding teaching (Flores, 2006; Hirst and Carr, 2005; Knight, 2002; Schön, 1987; Wenger, 1998). Far from being irrelevant to practice, Hugo (2013) demonstrates how insights obtained from educational theory are crucial for informing the professional knowledge-based decisions that teachers make in their practice: whether to incorporate or exclude learners' everyday knowledge from a learning process; the grounds upon which subject/topic boundaries are closed or opened to integration; and the epistemic grounds on which teachers make 
knowledge and pedagogic choices (knowledge selection, sequencing and pacing) in the topics/subjects they teach.

\section{Implications of recontextualising principles for the sequencing of knowledge in curricula}

The regional nature of education (which involves both disciplinary knowledge and the field of practice) presents unavoidable challenges for the design of coherent teacher education programmes (Bernstein, 2000). In the view of some (e.g. Cochran-Smith and Lytle, 1999; Levine, 2006) ITE curricula constructed to support the acquisition of theoretical teacher knowledge-for-practice demand a very different structure to those that promote the acquistion of contextually-bound teacher knowledge-in-practice. In this view, curricula that support the acquisition of different kinds of teacher knowledge are fundamentally incompatible. Others (e.g. Bertram and Christiansen, 2012; Grossman, 1990; Morrow, 2007) argue that decontextualised theoretical knowledge for education and contextually-bound practical knowledge make different contributions to support the development of teaching as a professional practice, however neither by itself constitutes a sufficient knowledge base for the development of professional teaching practice. The internal contradictions and inconsistencies that arise in curriculum design are therefore regarded as inevitable within curricula that seek to prepare prospective teachers. Recontextualising principles are important because they address these inconsistencies by bringing theoretical knowledge and practical knowledge into relation with one another in particular ways.

While some of the recontexualising principles may serve to complement or extend one another, others demand fundamentally incompatiable approaches. For example, preparing students with decontextualised knowledge that offers generalised insights over diverse contexts is fundamentally incompatiable with equipping student teachers with localised knowledge and skills to teach in specific contexts. The former works with an abstraction of the concept of teaching that transcends contextual particularities (and therefore has a strong semantic density), whereas the latter constructs teaching as a practice that is deeply embedded in contextual particularities (and therefore has a strong semantic gravity). Preparing teachers by consolidating and building on their personal experiences of schooling is fundamentally incompatible with an 
approach that seeks to distantiate students from their assumptions about teaching and then use concepts to help them think about existing and potential teaching practices in new ways. The first constructs further knowledge on teaching based on the everyday knowledge gained during students' own experiences of schooling and therefore sets up a process of teacher learning through assimilation. The latter, in constrast, analyses and problematises students' assumptions about teaching, and therefore sets teacher learning up as a process of accommodation (Piaget, 1976).

The process of learning to teach is a complex one, and it is unlikely that only one recontextualising principle will be sufficient. In some cases, it may be possible to minimise the internal inconsistencies that potentially arise from different recontextualising principles by bringing them into the foreground in a carefully considered sequence. In an extended professional qualification, like the four-year Bachelor of Education degree, there exists the possibility of introducing learning associated with different recontextualising principles at different points in time. A South African study by Amin and Ramrathan (2009) provides an interesting example of the gains and losses of sequencing choices. In this study, a teaching practicum for first-year student teachers was structured around a principle of contextual relevance (Recontextualising principle 1). Students observed teaching within contrasting contexts, and then were required to adapt a lesson plan for use in those contexts. The specifics of each context provided the basis for making appropriate pedagogic choices. However, without conceptual foundations provided by subject and pedagogic knowledge, student teachers translated their contextual awareness in mechanical and superficial ways in the lessons and resources they planned. Their limited reservoir of content and pedagogic knowledge effectively constrained the potential opportunities for deep and meaningful engagement with the intended recontextualising principle. The sequencing possibilities offered by an extended professional qualification allows for student teachers first to be introduced to teaching as a decontextualised, knowledge-based practice in which appropriate pedagogic decisions are made in relation to both the demands of the content and in response to the diverse needs of learners. Once students have acquired more of the conceptual tools for making appropriate pedagogic choices, the organising principle could then switch to one that foregrounds understanding the construction of diversity both historically and sociologically, and students could explore what it means to be pedagogically responsive to that diversity. In a similar vein, when student teachers are introduced upfront to the potential learning barriers that learners experience, it may be intended to prepare them to cope with learner diversity 
and inclusion from the outset. But without access to the subject and pedagogic knowledge to construct conceptually strong learning experiences, such an early introduction may inadvertently promote the technical application of superficial mechanical interventions, rather than a deep consideration of appropriate pedagogic options to support meaningful learning.

\section{Conclusion}

When teacher learning is organised around principles that foreground situational and practical knowledge, curricula tend to offer contextually relevant insights, and/or induct new teachers into existing practices; however, the acquisition of a systemitised body of theoretical knowledge is compromised. Education knowledge, while present, is selected in a contingent manner. Contextually coherent ITE curricula are designed around the kind of teacher learning that is most relevant in enabling newly qualified teachers to cope during the first few years of teaching. On the other hand, recontextualising principles that foreground theoretical knowledge offer more possibilities for ITE programmes to be conceptually coherent. To this end, the powerful knowledge that is least likely to be acquired through practical experience and personal reflection is privileged in formal university-based coursework. While these kinds of curricula enable prospective teachers to use insights from education theory to make rational pedagogical choices in practice, they may underprepare teachers for the immediate classroom-based realities. It is therefore quite likely that newly-qualified teachers would need to learn some of the more technical and administrative aspects of being a teacher on the job.

ITE programmes cannot on their own address the full range of challenges facing the South African education system. It is the responsibility for teacher educators to decide which of the many critical challenges their programmes should address and offer internally coherent programmes to that end. The knowledge selection principles discussed in this paper suggest approaches that offer particular ways of addressing the challenges, each with its own set of affordances and limitations. A fundamental challenge for those who design ITE curricula is to select recontextualising principles that offer the most purchase for powerful teacher learning in the limited time available. 


\section{References}

Alexander, R.J. 2000. Culture and pedagogy: international comparisons in primary education. Oxford: Blackwell.

Amin, N. and Ramrathan, P. 2009. Preparing students to teach in and for diverse contexts: a learning to teach approach. Perspectives in Education, 27(1): pp.69-77.

Balfour, R.J., Mitchell, C. and Moletsane, R. 2008. Troubling contexts: toward a generative theory of rurality as education research. Journal of Rural and Community Development, 3(3): pp.95-107.

Ball, D.L., Thames, M.H. and Phelps, G. 2008. Content knowledge for teaching: what makes it special? Journal of Teacher Education, 59, pp.389-407.

Bernstein, B. 2000. Pedagogy, symbolic control and identity: theory, research and critique (revised edition). Lanham: Rowman and Littlefield.

Bertram, C. and Christiansen, I. 2012. Editorial, Special Issue on Teacher Knowledge and Learning; Perspectives and Reflections. Journal of Education, 56: pp.1-16.

Carr, W. 2006. Education without theory. British Journal of Educational Studies, 54(2): pp.136-159.

Cochran-Smith, M. and Lytle, S. 1999. Relationships of knowledge and practice: teacher learning in communities. Review of Research in Education, 24: pp.249-305: American Educational Research Association.

Craib, I. 1992. Modern social theory: from Parsons to Habermas. New York: Harvester Wheatsheaf.

Department of Higher Education and Training. 2015. Policy on the Minimum Requirements for Teacher Education Qualifications, as revised 2014. Pretoria: Government Gazette. 
Fleisch, B. 2007. Primary education in crisis. Why South African schoolchildren underachieve in reading and mathematics. Cape Town: Juta and Co.

Flores, M. 2006. Being a novice teacher in two different settings: struggles, continuities, and discontinuities. Teachers College Record, 108(10): pp.2021-2052.

Gamble, J. 2006. Theory and practice in the vocational curriculum. In Young, M. and Gamble, J. (Eds), Knowledge, curriculum and qualifications for South Africa further education. Cape Town: HSRC Press, pp.87-103

Gardiner, M. 2008. Education in rural areas. In Pampallis, J. (Ed.), Issues in Education Policy (Vol. 4). Braamfontein: Centre for Education Policy Development, pp.1-33.

Gravett, S., Henning, E. and Eiselen, R. 2011. New teachers look back on their university education: prepared for teaching, but not for life in the classroom. Education as Change, 15 (sup1), S123-S142. doi:

10.1080/16823206.2011.643636

Gravett, S., Merseth, K. and De Beer, J. (Eds), 2013. Being a teacher: a book of cases. Cape Town: Pearson.

Grossman, P. 1990. The making of a teacher. Teacher knowledge and teacher education. New York and London: Teachers College Press.

Guile, D. 2014. Professional knowledge and professional practice as continuous recontextualisation: a social practice perspective. In Muller, J. and Young, M. (Eds), Knowledge, expertise and the professions. London: Routledge, pp.78-92.

Hammerness, K., Darling-Hammond, L., Bransford, J., Berliner, D., CochranSmith, M., McDonald, M. and Zeichner, K.M. 2005. How teachers learn and develop. In Darling-Hammond, L. and Bransford, J. (Eds), Preparing teachers for a changing world: what teachers should learn and be able to do. San Francisco: Jossey-Bass, pp.358-389.

Hirst, P.H., and Carr, W. 2005. Philosophy and Education - A Symposuim. Journal of Philosophy of Education, 39(4): pp.615-632. 
Hoban, G.F. 2005. Developing a multi-linked conceptual framework for teacher education design. In Hoban, G.F. (Ed.), The missing links in teacher education design. Springer, pp.1-17.

Hugo, W. 2013. Cracking the code to educational analysis. Cape Town: Pearson.

Knight, P. 2002. A systemic approach to professional development: learning as practice. Teaching and Teacher Education, 18: pp.229-241.

Korthagen, F. 2004. In search of the essence of a good teacher: towards a more holistic approach in teacher education. Teaching and Teacher Education, 20: pp.77-97.

Land, R., Cousin, G., Meyer, J.H. and Davies, P. 2005. Threshold concepts and troublesome knowledge (3): implications for course design and evaluation. In Rust, C. (Ed.), Improving student learning-equality and diversity. London: Oxford.

Levine, A. 2006. Educating school teachers. Washington: Education Schools Project.

Maton, K. 2007. Knowledge-knower structures in intellectual and educational fields. In Christie, F. and Martin, J.R. (Eds), Language, knowledge and pedagogy. Functional linguistic and sociological perspectives. London: Continuum pp.87-108.

Meyer, J.H.F. and Land, R. 2003. Threshold concepts and troublesome knowledge 1 - Linkages to ways of thinking and practising. In Rust, C. (Ed.), Improving student learning - ten years on. London: Oxford, pp.412-424.

Morrow, W. 2007. Learning to teach in South Africa. Pretoria: HSRC Press.

Mukeredzi, T.G. and Mandrona, A.R. 2013. The journey to becoming professionals: student teachers' experiences of teaching practice in a rural South African context. International Journal of Educational Research, 62: pp.141-151.

Muller, J. 2009. Forms of knowledge and curriculum coherence. Journal of Education and Work, 22(3): pp.205-226. 
Osman, R. 2010. The challenge and promise of university-based teacher education. Focus 56: On Teaching and Learning, 56: pp.21-25.

Petersen, N. and Henning, E. 2010. Design refinement tools for a teacher education curriculum: the example of a service learning course. Perspectives in Education, 28(4): pp.61-71.

Piaget, J. 1976. Piaget's theory. Berlin, Heidelberg: Springer.

Reeves, C. and Robinson, M. 2014. Assumptions underpinning the conceptualisation of professional learning in teacher education. South African Journal of Higher Education, 28(1): pp.236-253.

Samuel, M. 2002. Autobiographical research in teacher education. In Lewin, K., Samuel, M. and Sayed, Y. (Eds), Changing patterns of teacher education in South Africa: policy, practice and prospects. Sandown: Heinemann.

Samuel, M. 2008. Accountability to whom? For what? Teacher identity and the Force Field Model of teacher development. Perspectives in Education, 26(2): pp.3-16.

Samuel, M. 2009. Beyond the Garden of Eden: deep teacher professional development. South African Journal of Higher Education, 23(4): pp.739-761.

Schön, D.A. 1987. Educating the reflective practitioner: toward a new design for teaching and learning in the professions. San Francisco: Jossey-Bass.

Shalem, Y. 2014. What binds professional judgement? The case of teaching. In Young, M. and Muller, J. (Eds), Knowledge, expertise and the professions. London: Taylor and Francis.

Shalem, Y. and Slonimsky, L. 2013. Practical knowledge of teaching practice - what counts? Journal of Education, 58: pp.67-86.

Shay, S. 2013. Conceptualizing curriculum differentiation in higher education: a sociology of knowledge point of view. British Journal of Sociology of Education, 34(4): pp.563-582.

Shulman, L. 1987. Knowledge and teaching: foundations of the new reform. Harvard Educational Review, 57(1): p.1. 
Slonimsky, L. and Shalem, Y. 2006. Pedagogic responsiveness for academic depth. Journal of Education, 40: pp.35-58.

Taylor, N., Van der Berg, S. and Mabogoane, T. 2013. Creating effective schools. Cape Town: Pearson.

Welch, T. 2002. Teacher education in South Africa before, during and after apartheid: an overview. In Adler, J. and Reed, Y. (Eds), Challenges of teacher development. An investigation of take-up in South Africa. Pretoria: Van Schaik, pp.17-35

Wenger, E. 1998. Communities of practice: learning meaning and identity. New York: Cambridge University Press.

Wheelahan, L. 2010. Why knowledge matters in curriculum: a social realist argument. Oxfordshire: Routledge.

Whitelaw, S. De Beer, J. and Henning, E. 2008. New teachers in a pseudocommunity of practitioners. Education as Change, 1(2): pp.25-40.

Wiggins, G. and McTighe, J. 2005. Understanding by design (Vol. null).

Winch, C. 2014. Know-how and knowledge in the professional curriculum. In Young, M. and Muller, J. (Eds), Knowledge, expertise and the professions. London and New York: Routledge.

Young, M. 2008. Bringing knowledge back in. From social constructivism to social realism in the sociology of education. London and New York:

Routledge.

Young, M. and Muller, J. 2014. From the sociology of professions to the sociology of professional knowledge. In Muller, J. and Young, M. (Eds), Knowledge, expertise and the professions. London: Routledge, pp.3-17.

Lee Rusznyak

University of the Witwatersrand

lee.rusznyak@,wits.ac.za 
